\title{
ESTHETIC REHABILITATION WITH MINIMALLY INVASIVE FELDSPATHIC CERAMIC VENEERS: 30 MONTHS OF CLINICAL FOLLOW-UP
}

\author{
REABILITAÇÃO ESTÉTICA COM FACETAS EM CERÂMICAS FELDSPÁTICAS \\ MINIMAMENTE INVASIVAS: 30 MESES DE ACOMPANHAMENTO CLÍNICO
}

\section{Paulo Vinícius SOARES ${ }^{1}$; Larissa de Ávila DUARTE² Guilherme Faria MOURA $^{3}$; Lívia Fávaro ZEOLA ${ }^{3}$; Analice Giovani PEREIRA ${ }^{4}$; Alexandre Coelho MACHADO ${ }^{3}$}

1. Coordinator of Nucleus Extension, Research, and Teaching at NCCLs Research Group. Professor at Department of Operative Dentistry and Dental Materials, School of Dentistry, Federal University of Uberlandia, Uberlandia, Brazil. paulovsoares@yahoo.com.br; 2. Graduate Student, Dental School, Federal University of Uberlandia, Uberlandia, Brazil; 3. Member of Nucleus Extension, Research, and Teaching at NCCLs Research Group. Postgraduate student at Department of Operative Dentistry and Dental Materials, School of Dentistry, Federal University of Uberlandia, Uberlandia, Brazil; 4. Member of Nucleus Extension, Research, and Teaching at NCCLs

Research Group. Professor at Endodontic Department, School of Dentistry, Federal University of Uberlandia, Uberlandia, Brazil.

\begin{abstract}
Diastemas among maxillary incisors and gingival contour disharmony are common findings among patients in dental practice. Ceramic veneers are indicated for esthetic rehabilitation of anterior diastemas due their predictable results, optical characteristics, fracture resistance and tooth structure conservation. However, because it is a friable material and have a brittle behavior, fractures occurrences are related to trauma, oclusal overload, parafunctional habits and material fatigue. This article describes 30 months follow-up of an esthetic and functional rehabilitation diastemas closure using feldspathic veneers associated with periodontal surgery and a ceramic repair with composite resin. Gingivectomy and frenectomy needs were found and the surgical procedures performed guided by new anatomic aspects of the crowns. Mock-up was performed after waxing and reverse planning. All anterior teeth underwent minimally invasive preparation. Feldspathic ceramic veneers were made, tried using try in paste and luted with light-cure resin cement. After 24 months, a fracture occurred on the right maxillary canine veneer. The ceramic restoration repair was performed with nano-hybrid composite resin, after the conditioning with 5\% hydrofluoric acid, 37\% phosphoric acid and silane couple agent. The combination between ceramic veneers and gingivectomy enables to obtain conservative treatments and esthetic success. After six months of the repair, resulting 30 months of follow-up, the anterior restorations were aesthetically and functionally satisfactory.
\end{abstract}

KEYWORDS: Ceramic restoration repair. Conservative preparation. Diastemas closure. Esthetic dentistry. Gingivectomy. Laminated ceramic veneers.

\section{INTRODUCTION}

Diastemas are classified as the presence of inappropriate space distribution in anterior region or tooth size discrepancy, which promotes aesthetic impairment (WOLFF et al., 2010). It is a common alteration among adult population that increases with age and the incidence ranges from $1.7 \%$ to $38 \%$ (MORAIS et al., 2014). The presence of multiple anterior diastemas (BARRETO et al., 2013) associated with gingival disharmony; influence negatively the aesthetics of the smile (PINTO et al., 2013).

Among the techniques of diastemas closure, orthodontic movement, direct restoration with composite resin, and indirect prosthetic procedures are indicated (BLATZ; HURZELER; STRUB, 1999). In indirect procedures, feldspathic ceramics veneers are indicated and represent an excellent treatment alternative (GRESNIGT; KALK; OZCAN, 2013; MORIMOTO et al., 2016). The ceramic restorations present high color and surface smoothness stability when compared to composite resin (GAROUSHI et al., 2013). Feldspathic glass ceramics also present high translucence and fracture resistance after the cementation, which makes it suitable for minimally invasive veneer esthetic rehabilitation (MORIMOTO et al., 2016).

Besides the lack of teeth esthetic harmony, the gingival tissue level, smile line and periodontal morphology may contribute to unpleased appearance impact (PINTO et al., 2013). The balance of the gingival architecture is essential in defining shapes and contours of the teeth. In order to achieve excellent functional and esthetic results, once gingival level and smile line are unsatisfying, a multidisciplinary approach is required to reestablish the harmony between dental and gingival parameters (PINTO et al., 2013). Therefore, gingivectomy is necessary to increase the length of anterior teeth clinical crowns, and also to promote harmonious gingival contour (PINTO et al., 2013). 
Owing the need to improve diastemas and periodontal-compromised esthetics, and within successful evidences of feldspathic ceramics (MORIMOTO et al., 2016), as well as the role played by gingival architecture in the composition of the smile, this article approach a clinical case report describing gingivectomy and a 30 months follow-up of diastemas closure using feldspathic veneers and a ceramic repair with composite resin.

\section{CASE REPORT}

The patient, a 21-year-old woman, presented to the School of Dentistry of Federal University of Uberlandia, displeased with her smile. Clinical examination revealed diastemas presence among all maxillary incisors and disharmony of gingival tissue morphology, with the upper labial frenum inserted next to the gingival papilla (Figure 1- A and B). The assessment of occlusal parameters was performed by making models and mounting on a semi-adjustable articulator. Despite the diagnosis of bruxism, premature contacts and occlusal interference were not verified. By analyzing radiographies, teeth and periodontal sustention structures presented no alterations and also no osseous remodeling on alveolar ridge showed necessary. The treatment approach was planned associating gingivectomy surgery and frenectomy, and then crowns shape rehabilitation using indirect minimally invasive feldspathic ceramic veneers.

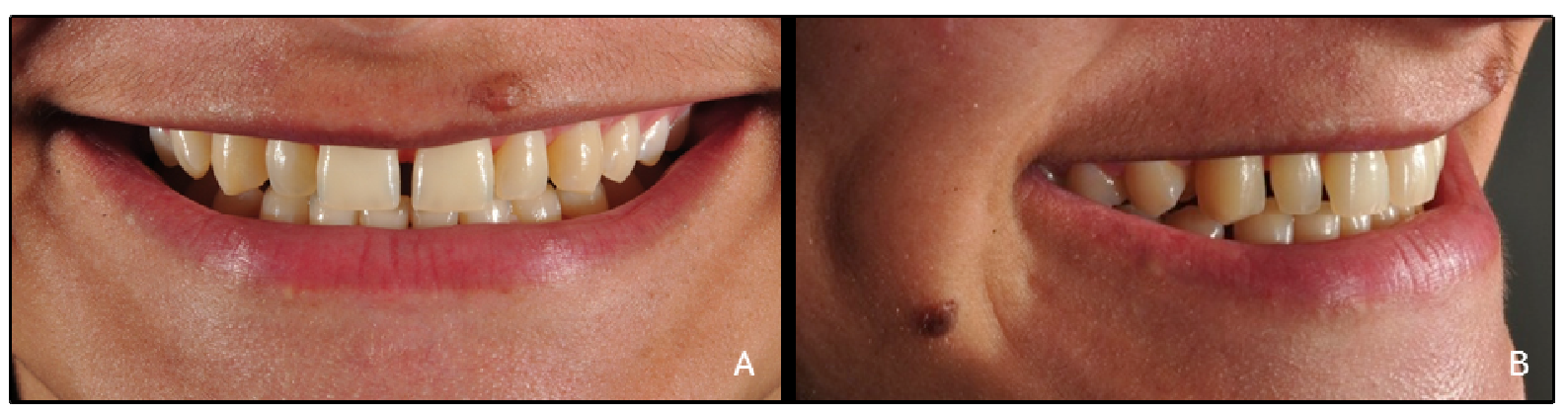

Figure 1. Initial appearance of patient's smile. A- Buccal view of diastemas. B- Lateral view of diastemas.

The digital smile design (a virtual planning that utilizes patient input and information gathered through diagnostic procedures to create an esthetic treatment scheme) was performed on a computer software (PowerPoint 2010, Micorsoft Office, Redmond, WA, USA) through dental dimensions measures and photographic protocol, simulating the dental and periodontal proportions, anatomical aspects and aesthetics principles. According to the treatment planning and digital smile design, gingivectomy was performed with local anesthesia $2 \%$ lidocaine with $1: 100,000$ epinephrine
(Alphacaine, DFL, Rio de Janeiro, RJ, Brazil) and external bevel technique was performed on the anterior masticatory mucosa. For frenectomy procedure, parallel incisions along the labial frenum, buccal surfaces and on the alveolar ridge were performed. Frenum fibers were fully incised and the flap sutured with simple isolated points (Figure 2A). The aspect at 45 days after surgery procedures showed harmony of the smile line and soft tissue architecture, beyond increased clinical crowns of the teeth (Figure 2-B).

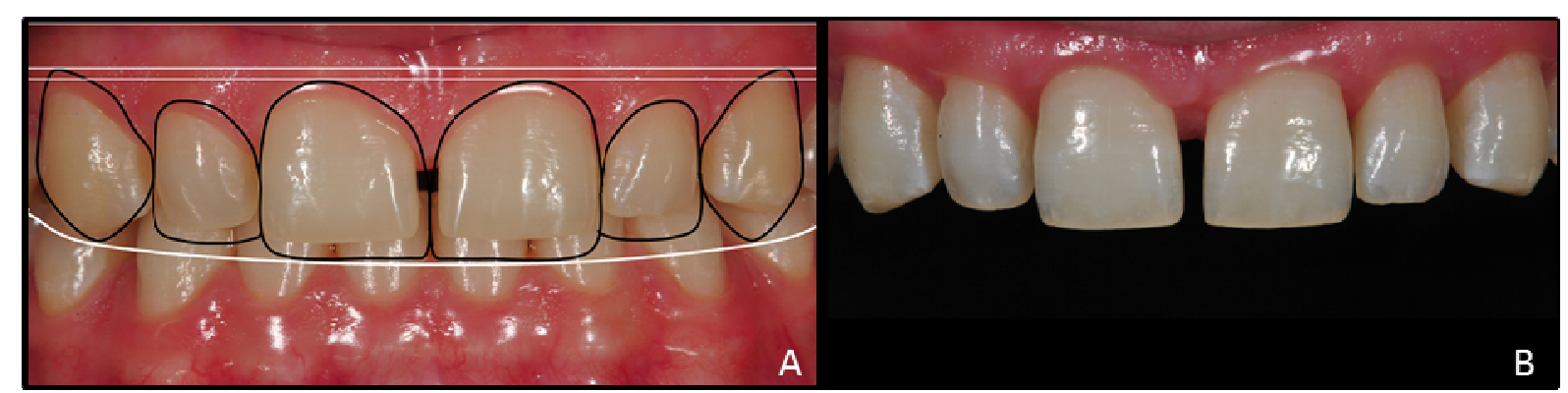

Figure 2. Gingival appearance before and after the gingivectomy and frenectomy. A- Digital smile design oriented in relation to dental and periodontal aesthetics. B- The aspects 45 days after the periodontal surgery. 
After waxing the desired new teeth anatomy based on the digital smile design, impression using a putty addition silicone (Express XT; 3M ESPE, St Paul, MN, USA) was done (Figure 3-A). In a single step, silicone matrix was trimmed, filled with bisacrylic resin (Protemp; 3M ESPE, St Paul, MN, USA) and brought into position for obtaining the mock-up (Figure 3-B). At this moment, the areas and the depth of teeth wear were planned according to the bis-acrylic resin thickness and enamel exposition. Minimally invasive veneers were planned for anterior teeth for all maxillary anterior teeth. The conservative preparations were performed in enamel only, using a diamond bur (\#2135FF, KG Sorensen, Cotia - São Paulo, Brazil) (Figure 4A)and proposes to eliminate retention areas and rounded the angles (Figure 4-B).

After teeth preparations and gingival displacement using retraction cords (\#000; Ultradent, South Jordan, Utha, USA) impression was performed with addition silicone. The ceramic shade was designated as A1 with incisive characterization due to the translucence. Feldspathic glass-ceramic (Shofu Vintage AL; Shofu, Kyoto, Japan) were applied by stratification technique on refractory for veneers confection.

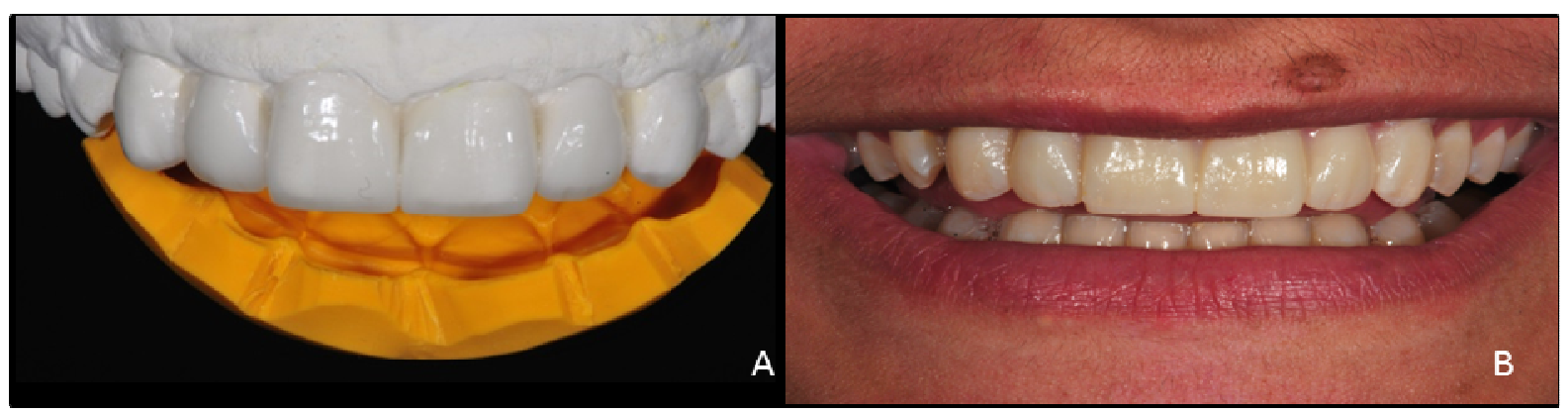

Figure 3. Reverse planning. A- Study model and diagnostic wax-up with silicone matrix. B- Analysis and adjustment of mock-up.

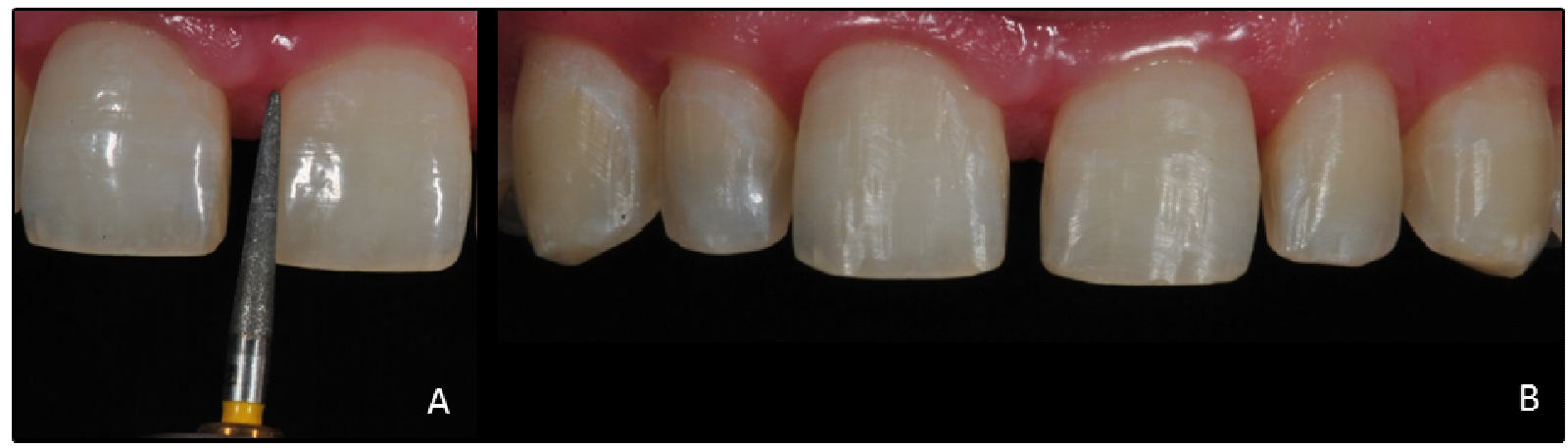

Figure 4. A- Minimally invasive preparation with extra-fine diamond burn. B- Aspects after the preparation.

Proximal and cervical adaptation, periodontal relationship and asymmetries were checked on the veneers proof. The cement color was selected and tested using try-in paste (Variolink Veneer Try-In; Ivoclar Vivadent, Schaan, Liechtenstein). The veneers internal surfaces were etched using 10\% hydrofluoric acid (PowerCething 10\%; BM4, Palhoça, Santa Catarina, Brazil) during $120 \mathrm{~s}$ and washed. Then, $37 \%$ phosphoric acid (Poweretching 37\%, BM4, Palhoça, Santa Catarina, Brazil) was applied and rubbed for $60 \mathrm{~s}$. After the rinse, the internal surface was dried with air jets and the veneers were silanized with silane coupling agent for 60s (Monobond Plus; Ivoclar Vivadent, Schaan, Liechtenstein). The enamel was conditioned by $37 \%$ phosphoric acid for 30 s, rinse for 30 s and dried with air jets. All preparations received one layer of the bond adhesive (Excite F DSC; Ivoclar Vivadent, Schaan, Liechtenstein).

For the veneers luting, photo-cured resin cement (Variolink Veneer; Ivoclar Vivadent Schaan, Liechtenstein) was used. Excess of the cement was removed and each surface light-cured for 60s using LED $1200 \mathrm{~mW} / \mathrm{cm}^{2}$ (Radii Plus; SDI, Bayswater, Victoria, Australia). Occlusal contacts, protrusive and lateral movements were checked. In the same session, an occlusal splint was confectioned to control the bruxism and preserve the ceramic veneers (Figure 5- A and B). 


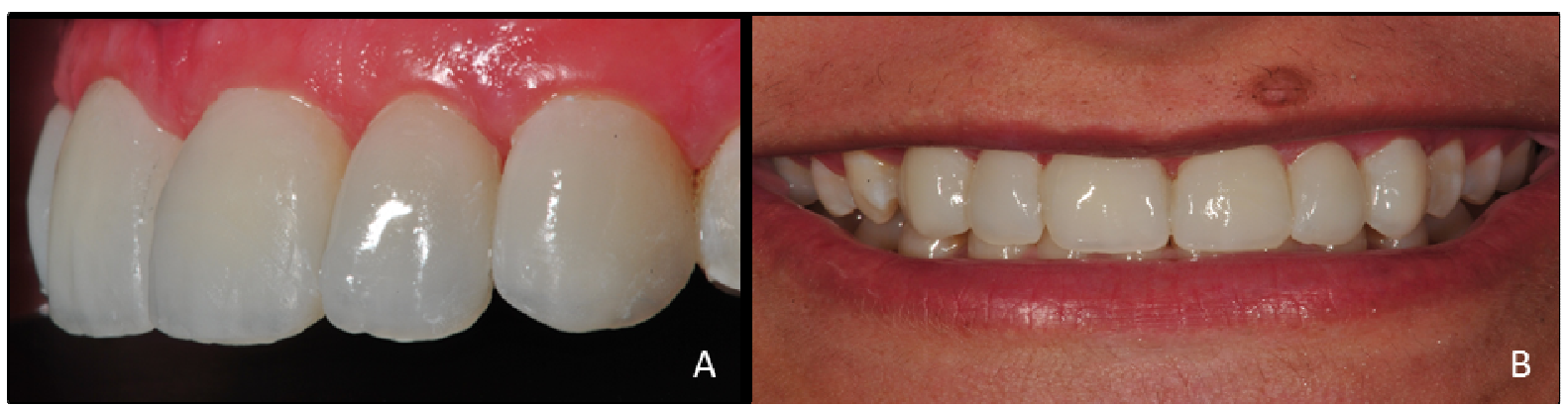

Figure 5. Immediately final appearance of rehabilitation. A- Lateral dental view. B- Buccal view of patient's smile.

No clinical complications were observed until the 24-mounth follow-up. Unfortunately, after this period, the patient reported have forgetting to sleep with the oclusal splint and a fracture on ceramic veneer of right maxillary canine occurred (Figure 6-A). The fracture was carefully evaluated, and due to the fracture extension it was decided to perform the ceramic restoration repair with composite resin. The anterior maxillary teeth were isolated with rubber dam and 5\% hydrofluoric acid (PowerCething 5\%; BM4, Palhoça, Santa Catarina, Brazil) were applied on the ceramic close to the fracture line for 60s. Posteriorly, the $37 \%$ phosphoric acid was applied booth in ceramic and enamel, and rinsed for 30s. The silane couple agent was applied on the ceramic surface and after $60 \mathrm{~s}$ the bond was applied on ceramic and enamel. A nano-hybrid composite resin shade A1 (Palfique LX5, Tokuyama Dental, Tokyo, Japan) was inserted promoting the esthetic and function impaired consequent of the fracture (Figure 6-B, C and D). The finishing and polishing were performed and a new oclusal splint was confectioned (Figure 6-E). After six months of the repair, resulting in 30 months of follow-up, the esthetic restoration was aesthetically and functionally satisfactory (Figure 7A and B).

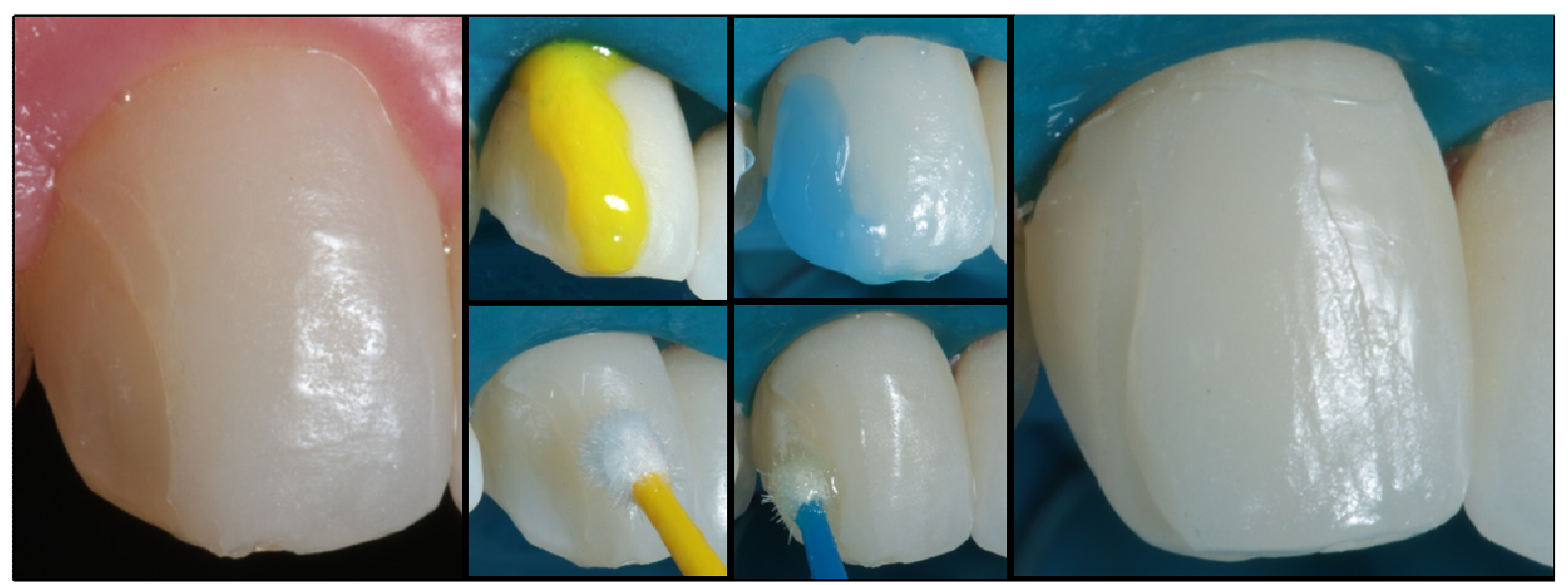

Figure 6. Ceramic repair. A- Maxillary right canine's veneer fracture. B, C and D- 5\% hydrofluoric acid, 37\% phosphoric acid, and silane application, respectively. E- Final ceramic veneer repair with composite resin.

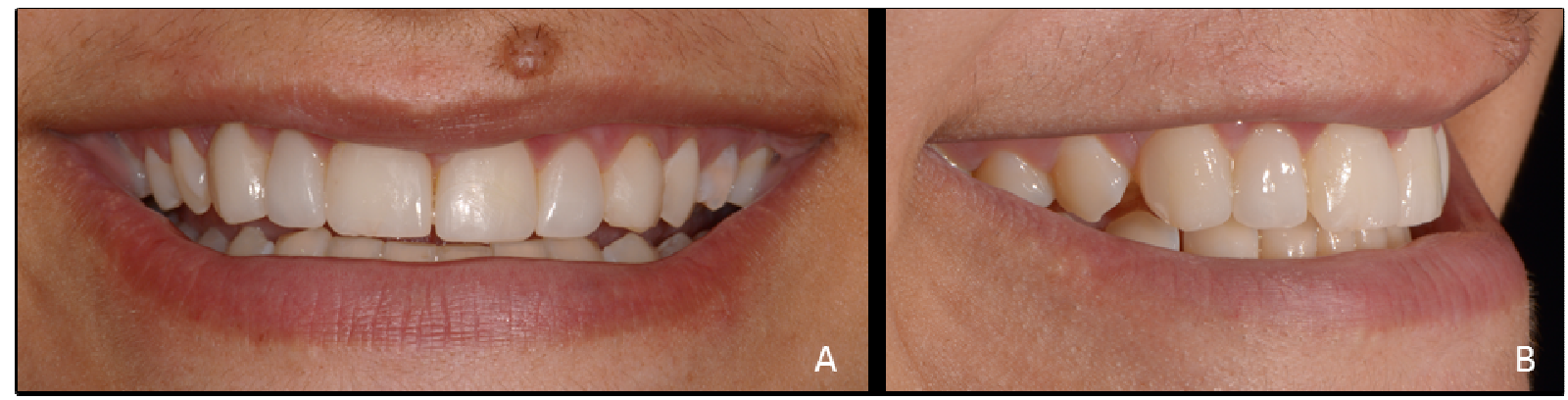

Figure 7. Patient's smile after 30 months of clinical follow-up. A- Buccal view. B- Lateral view. 


\section{DISCUSSION}

The gingivectomy technique produces satisfactory results in cases that the patient presents excessive gingival tissue and no need of bone remodeling interventions. This procedure enables the exposure of hidden enamel under gingival tissue and achieves harmony in gingival architecture due to gingival tissue excess removal. Upper labial frenum removal is appropriate once an abnormal frenum is capable of retracting the gingival margin, creating a diastemas, limiting lip movement, and in cases of a high smile line, affecting esthetics also (DELLI et al., 2013). Gingivectomy and frenectomy play important role on oral esthetic balance due to the importance of the harmony between teeth and gingiva in achieving a pleasant smile.

Reverse planning by digital smile design, waxing-up restorations and mock-up provides security in the execution of a functional and aesthetic treatment. Mock-up favors achieving predictable results once it enables previous analysis of teeth shape, size, symmetry, optimal incisal level and gingival architecture account before performing the definitive treatment. Occlusal contacts balance, free mandibular movements, labial support and smile line can be checked and adjusted on mock-up step providing increased predictability to the treatment (SOARES et al., 2014).

The improvements of dental materials have made ceramic a desirable option for indirect aesthetic restorative procedures (GRESNIGT; KALK; OZCAN, 2013; MORIMOTO et al., 2016). The cumulative survive rate is $87 \%$ with a medium followed-up of 8 years for feldsptathic ceramics (MORIMOTO et al., 2016). For this reason ceramic veneers became a predictable and conservative option for rehabilitating shape and size of esthetically compromised teeth. The small amount of preparation that allows teeth wear limited to enamel makes the technique appropriate once the dentistry increasingly recommends conservative procedures. According to the data found in the literature by the authors, the mean of clinical follow-up nearest to this clinical report evaluation period was 21.6 months (GRESNIGT; KALK;
OZCAN, 2013). In this period, the feldspathic ceramic veneers obtained survival rate of $94.6 \%$. The main failures were slight marginal defects and slight marginal discoloration at the margin. Moreover, the most common absolute failure was fracture and chipping, though there was the observation of debonding.

The difficulty to remove the restorations preserving dental tissue, the high cost of ceramic restoration replacement and the need for immediate resolution expected by the patient justify the intraoral repair of the fracture area with composite resin as an esthetic and functional alternative (RAPOSO et al., 2009). In spite of the advantages of dental materials, restorative materials and adhesive interfaces are subject to failure due to stress concentration. Because ceramic is a friable material and have a brittle behavior, fractures occurrences are related to trauma, oclusal overload, parafunctional habits and material fatigue. For this same reason, the composite resin is the most suitable material for performing intra-oral ceramic repair, as it has adhesive properties that promote a single set of structure according to biomechanical principles, preventing cracks propagation (SOARES et al., 2008). For this, the use of a ceramic conditioner (hydrofluoric acid) followed by application of a silane bonding agent is essential for obtain satisfactory union between the restoratives materials. Moreover, composite resin is a material that allows performing stratification layers according to shade, translucency and opalescence. However, the option for the repair does not mean that this is the ideal treatment, but promotes satisfactory results with lower costs and reduced clinical sessions (RAPOSO et al., 2009).

\section{CONCLUSION}

The multidisciplinary approach allowed recovering the smile aesthetics of patients affected by maxillary diastemas and disharmonic gingival morphology. Patient remained satisfied with the indirect restorations aesthetic and the repair performed with composite resin is an esthetics and functional alternative for ceramic fractures.

RESUMO: Presença de diastemas entre os incisivos superiores e desarmonia do contorno gengival são achados comuns entre os pacientes atendidos na rotina clínica. Facetas cerâmicas são indicadas para reabilitação estética de diastemas anteriores devido a previsibilidade de resultados, características óticas, resistências à fratura e conservação de estrutura dentária. Entretanto, por este ser um material frágil e apresentar comportamento friável, fraturas podem estar relacionadas a episódios de trauma, sobrecarga oclusal, hábitos parafuncionais e fadiga do material. Este artigo descreve um acompanhamento clínico de 30 meses de reabilitação estética e funcional de fechamento de diastema utilizando facetas minimamente invasivas confeccionadas com cerâmicas feldspáticas associadas à cirurgia periodontal e necessidade de 
reparo da cerâmica com resina composta. A indicação de plastia gengival e frenectomia foram constatadas e o procedimento cirúrgico guiado pelo planejamento da nova anatomia das coroas dentárias. Todos os dentes anteriores superiores foram minimamente preparados. O mock-up foi realizado depois do enceramento e do planejamento reverso. Facetas em cerâmicas feldspáticas foram confeccionadas, a cor do cimento resinoso selecionada com pastas testes e a cimentação concluída com cimento de polimerização exclusiva física. Depois de 24 meses de acompanhamento, ocorreu fratura da faceta do canino superior direito. O reparo da restauração cerâmica foi realizado com resina nanohibrida, depois da cerâmica condicionada com ácido fluorídrico 5\%, ácido fosfórico 37\% e aplicação de agente de união silano. A combinação entre facetas cerâmicas e cirurgia de plastia gengival permite alcançar tratamento conservador e sucesso estético. Posteriormente seis meses do reparo, resultando em 30 meses de acompanhamento clínico, as restaurações anteriores permaneciam estética e funcionalmente satisfatórias.

PALAVRAS-CHAVES: Facetas laminadas cerâmicas. Fechamento de diastema. Odontologia estética. Gengivectomia. Preparos minimamente invasivos.

\section{REFERENCES}

BARRETO, C.; LIMA, A. F.; CATELAN, A.; DA SILVA, G. R.; GAGLIANONE, L. A.; MARTINS, L. R.; AGUIAR, F. H.; SOARES, C. J. A complete esthetic approach with multiple diastemata in anterior teeth: 1year follow-up. Gen Dent, Chicago, v. 61, n. 2, p. 54-56, 2013.

BLATZ, M. B.; HURZELER, M. B.; STRUB, J. R. Reconstruction of the lost interproximal papilla-presentation of surgical and nonsurgical approaches. Int J Periodontics Restorative Dent, Chicago, v. 19, n. 4, p. 395-406, 1999.

DELLI, K.; LIVAS, C.; SCULEAN, A.; KATSAROS, C.; BORNSTEIN, M. M. Facts and myths regarding the maxillary midline frenum and its treatment: a systematic review of the literature. Quintessence Int, Berlim, v. 44, n. 2, p. 177-187, 2013.

GAROUSHI, S.; LASSILA, L.; HATEM, M.; SHEMBESH, M.; BAADY, L.; SALIM, Z.; VALLITTU, P. Influence of staining solutions and whitening procedures on discoloration of hybrid composite resins. Acta Odontol Scand, Stockholm, v. 71, n. 1, p. 144-150, 2013. http://dx.doi.org/10.3109/00016357.2011.654253

GRESNIGT, M. M.; KALK, W.; OZCAN, M. Clinical longevity of ceramic laminate veneers bonded to teeth with and without existing composite restorations up to 40 months. Clin Oral Investig, Berlim, v. 17, n. 3, p. 823-832, 2013. http://dx.doi.org/10.1007/s00784-012-0790-5

MORAIS, J. F.; FREITAS, M. R.; FREITAS, K. M.; JANSON, G.; CASTELLO BRANCO, N. Postretention stability after orthodontic closure of maxillary interincisor diastemas. J Appl Oral Sci, Bauru, v. 22, n. 5, p. 409-415, 2014. http://dx.doi.org/10.1590/1678-775720130472

MORIMOTO, S.; ALBANESI, R. B.; SESMA, N.; AGRA, C. M.; BRAGA, M. M. Main Clinical Outcomes of Feldspathic Porcelain and Glass-Ceramic Laminate Veneers: A Systematic Review and Meta-Analysis of Survival and Complication Rates. Int J Prosthodont, Lombard, v. 29, n. 1, p. 38-49, 2016. http://dx.doi.org/10.11607/ijp4315

PINTO, R. C.; CHAMBRONE, L.; COLOMBINI, B. L.; ISHIKIRIAMA, S. K.; BRITTO, I. M.; ROMITO, G. A. Minimally invasive esthetic therapy: a case report describing the advantages of a multidisciplinary approach. Quintessence Int, Berlim, v. 44, n. 5, p. 385-391, 2013.

RAPOSO, L. H.; NEIVA, N. A.; DA SILVA, G. R.; CARLO, H. L.; DA MOTA, A. S.; DO PRADO, C. J.; SOARES, C. J. Ceramic restoration repair: report of two cases. J Appl Oral Sci, Bauru, v. 17, n. 2, p. 140-144, 2009. http://dx.doi.org/10.1590/S1678-77572009000200013 
SOARES, P. V.; SANTOS-FILHO, P. C.; GOMIDE, H. A.; ARAUJO, C. A.; MARTINS, L. R.; SOARES, C. $\mathrm{J}$. Influence of restorative technique on the biomechanical behavior of endodontically treated maxillary premolars. Part II: strain measurement and stress distribution. J Prosthet Dent, St. Louis, v. 99, n. 2, p. 114122, 2008. http://dx.doi.org/10.1016/S0022-3913(08)60027-X

SOARES, P. V.; SPINI, P. H.; CARVALHO, V. F.; SOUZA, P. G.; GONZAGA, R. C.; TOLENTINO, A. B.; MACHADO, A. C. Esthetic rehabilitation with laminated ceramic veneers reinforced by lithium disilicate.

Quintessence Int, Berlim, v. 45, n. 2, p. 129-133, 2014.

WOLFF, D.; KRAUS, T.; SCHACH, C.; PRITSCH, M.; MENTE, J.; STAEHLE, H. J.; DING, P.

Recontouring teeth and closing diastemas with direct composite buildups: a clinical evaluation of survival and quality parameters. J Dent, Bristol, v. 38, n. 12, p. 1001-1009, 2010.

http://dx.doi.org/10.1016/j.jdent.2010.08.017 